\title{
Measurement and calculation of the critical pulsewidth for gain saturation in semiconductor optical amplifiers
}

Borri, Paola; Mørk, Jesper; Hvam, Jørn Märcher; Merozzi, A.

Published in:

Lasers and Electro-Optics Europe, 1998. 1998 CLEO/Europe. Conference on

Publication date:

1998

Document Version

Publisher's PDF, also known as Version of record

Link back to DTU Orbit

Citation (APA):

Borri, P., Mørk, J., Hvam, J. M., \& Merozzi, A. (1998). Measurement and calculation of the critical pulsewidth for gain saturation in semiconductor optical amplifiers. In Lasers and Electro-Optics Europe, 1998. 1998 CLEO/Europe. Conference on IEEE.

\section{General rights}

Copyright and moral rights for the publications made accessible in the public portal are retained by the authors and/or other copyright owners and it is a condition of accessing publications that users recognise and abide by the legal requirements associated with these rights.

- Users may download and print one copy of any publication from the public portal for the purpose of private study or research.

- You may not further distribute the material or use it for any profit-making activity or commercial gain

- You may freely distribute the URL identifying the publication in the public portal 
CTul60

\section{Nonlinear compression of tilted light pulses}

R. Donielius, A. Dubietis, G. Valiulis, G. Tamošauskas, A. Piskarskas Vilmizis University Laser Research Center, Sauletekio Avenue 9, building 3, 2040 Vilmius, Lithuania

$$
\begin{aligned}
& \text { 20-40 Whimus, Lithuania } \\
& \text { tel }:+370-2769477 . \text { fax: }+370-2775623
\end{aligned}
$$

e-mail audrius.dubietis@ff.vu.lt

Summary

Nonlinear pulse compression under special conditions of large group-velocity mismatch (GVM) and strong energy exchange suggested for the first time 8 years ago [1,2], was demonstrated to be a simple and efficient method to generate powerful ferntosecond pulses via frequency doubling of picosecond Nd-laser pulses in KDP crystal. However, the dircet transfer of this technique to other wavelengths or other well-developed laser sources (Ti:sapphire, for instance) encounters serious problems related to the lack of nonlinear erystals with suitable dispersive properties. To this regard, the use of tilted pulses offers unique possibility to adjust the GVM in a nontinear erystal for a particular wavelength $[3,4]$.

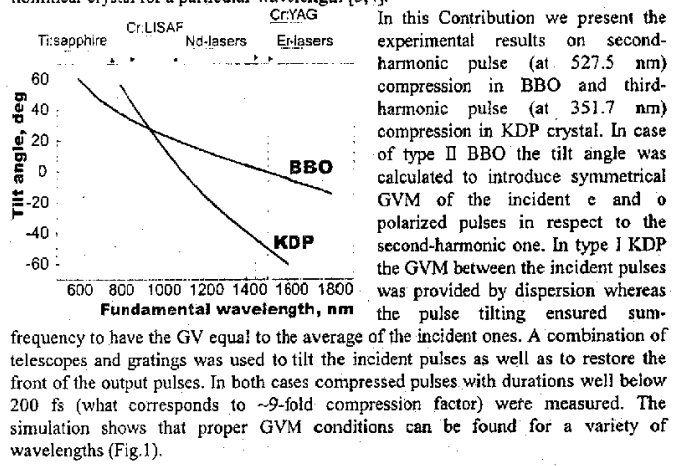

References:

1. Y. Wang and R. Dragila, Phys. Rev. A 41 (1990) 5645

2. A. Stabinis, G. Valjulis, and E. A. Jbragimov, Opt. Comm. 86 (1991) 301

3. A. Dubietị, G. Yaliulis, G. Tamošauskas, R. Danielius, and A. Piskarskas, Opt. Lett. 22, 1071 (1997).

4. A. Dubietis, G. Valiulis, G. Tamošauskas, R. Danielius, and A. Piskarskas, Opt. Comm. $144,55(1997)$.

\section{CTul61}

Measurement and calculation of the critical pulsewidth for gain

saturation in semiconductor optical amplifiers

P. Borri, J. Mørk, and J. M. Hvam,

Mikroelektronik Centret, The Technicai Universit of Denmark DK-2800 Lyngby,

Dennark. Tel: +4545255745 ; Fax: +4545887762 ; e-mail. paola@mic.dtu.dk

A. Mecozzi,

Fondazione Ugo Bordoni, via B. Castiglione 59, 00l42 Roma, laty:

Active semiconductor optical waveguides are essential components in many recently proposed devices for high-speed optical signal processing. It is well known that ul|trefast carrier dynamics, like carrier heating and spectral holeburning, lead to gain non-line arities, which restrict the modulation bandwidth of semiconductor lasers. In the case of pulse amplification, these non-linearities lead to a pulsewidt dependence of the gain saturation [I]. A critical pulsewidth can be defined [2], which separates two qualitatively different regimes: a long-pulse regime, where the gain is determined by the pulse energy only, and a short-pulse regime, where the guin also depends on the pulsewidth. Calculated critical pulsewidths are on the order of severa picosecands [1] which is getting in the rance of pulses bein expiored for ulrafost picoseconts oplical sigh prose ex

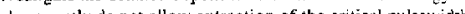

We have measured the gain saturation of a 250 um-long InGaAsP optical amplifies operating at $1.55 \mu \mathrm{m}$, for pulse durations from 200 is $1010 \mathrm{ps}$. Infrared pulses of $200 f s$ are generated using the idler of an optical parametric amplifier. Longer pulsewidths and linear chirp compensation are achieved using a pulse-shaper in the beam path. Cross correlation measurements show that the pulses are background-free.

The measured amplifier gain as a function of output energy' (in the range from $5 \mathrm{fJ}$ to $5 \mathrm{pJ}$ ) clearly shows that the on set of gain saturation is pulsewidth dependent. By ploting the corresponding $3 \mathrm{~dB}$ output energy as a function of the pulse duration we deduce a critical pulsewidth, for which the saturation induced by depletion of the carrier density (sometimes denoted linear gain saturation) equals the saluration due to ullerafast carrier dynamics. We obtain critical pulsewidths in the range from 2 10 $7 \mathrm{ps}$ depending on the optical wavelength and bias cuirent. Note that these yalues are significantly farger than the relaxation time of the carrier plasma temperature $\left(\tau_{T} \approx 700\right.$ fs). However, as the pulsewidth becomes comparable to and shorter than $\tau_{T}$ the variation of saturation energy with pulsewidth changes qualitatively, depending on whether the main saturation mechnism comes from spectral hoteburning or carrier Whether the main saturation mechanimm comes from spectal holeburning or carrier to larger role of carrier heating at shorter wavelengths.

[1] Y. Lai, K. L. Hall, E. P. Ippen, and G. Eisenstein, IEEE Photon. Technol. Let1. 2, $7 / 1$ (1990). R. S. Grant and W. Sibbett, Appl. Phys, Lett. 58, 1119 (1991)

[2] A. Mecozzi and J. Mark, JEEE J. Select. Topics in Quant. Electron, Oct. 1998. 